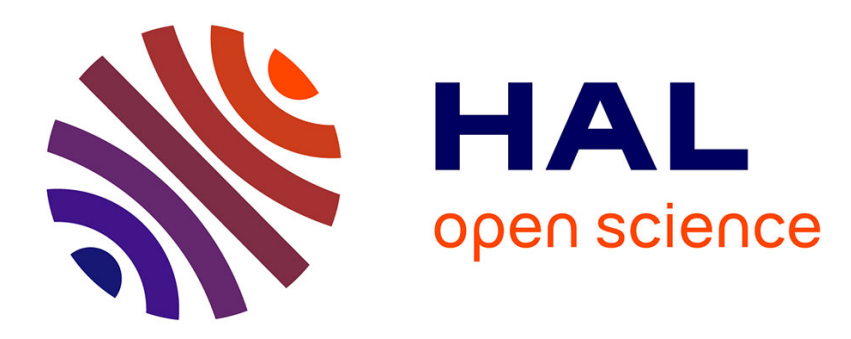

\title{
Uniaxial stress apparatus for neutron scattering
}

A. Draperi, C. Vettier

\section{To cite this version:}

A. Draperi, C. Vettier. Uniaxial stress apparatus for neutron scattering. Revue de Physique Appliquée, 1984, 19 (9), pp.823-824. 10.1051/rphysap:01984001909082300 . jpa-00245270

\section{HAL Id: jpa-00245270 https://hal.science/jpa-00245270}

Submitted on 1 Jan 1984

HAL is a multi-disciplinary open access archive for the deposit and dissemination of scientific research documents, whether they are published or not. The documents may come from teaching and research institutions in France or abroad, or from public or private research centers.
L'archive ouverte pluridisciplinaire HAL, est destinée au dépôt et à la diffusion de documents scientifiques de niveau recherche, publiés ou non, émanant des établissements d'enseignement et de recherche français ou étrangers, des laboratoires publics ou privés. 


\title{
Uniaxial stress apparatus for neutron scattering
}

\author{
A. Draperi $(*)$ and C. Vettier $\left(^{+}\right)$ \\ (*) Laboratoire Louis Néel, CNRS, 166X, 38042 Grenoble Cedex, France \\ $\left({ }^{+}\right)$Institut Laue-Langevin, 156X, 38042 Grenoble Cedex, France
}

\begin{abstract}
Résumé. - On décrit un dispositif pour l'application de forces de compression uniaxiale jusqu'à 1500 daN. On peut faire varier cette force appliquée de façon continue même à basse température. Les expériences de diffusion neutroniques permettent de vérifier l'homogénéité de la contrainte appliquée. D'autres types d'expériences sous contrainte uniaxiale, comme les mesures de vitesse de propagation sonore ou de susceptibilité, sont ainsi possibles grâce à ce dispositif.
\end{abstract}

\begin{abstract}
We describe an apparatus which permits experiments on single crystals subjected to uniaxial forces up to $1500 \mathrm{daN}$. Applied load can be varied continuously even at low temperature. Neutron scattering experiments have shown that the stress distribution is uniform in the sample. Other experiments, such as susceptibility or sound velocity measurements can also be performed under uniaxial stress conditions by using this versatile apparatus.
\end{abstract}

\section{Introduction.}

Application of uniaxial stress is a useful probe for the investigation of symmetry properties of solids. Many experimental devices have been developed which permit different types of measurements including scattering experiments $[1,2]$. Neutron scattering experiments impose geometrical constraints. In particular, the direction of the applied stress with respect to the scattering plane is a crucial parameter. Furthermore, materials must be transparent to neutron beams.

In this note, we describe a simple device which permits experiments on single crystals subjected to continuously variable unixial stress at low temperature. The applied load is perpendicular to the neutron scattering plane.

\section{Description.}

The apparatus has been designed for working at low temperature. It can fit into a standard helium flow cryostat with a $70 \mathrm{~mm}$ bore. Temperature of the sample down to $1.5 \mathrm{~K}$ can be achieved.

The desired load is applied to the sample by two opposite pistons activated from the ouside of the cryostat. The force is transmitted to the pistons by two stainless steel tubes and an aluminium alloy (7049 A-T6) sleeve (Fig. 1). Windows have been cut into the sleeve to allow for sample mounting. Pistons and guide holes must be carefully treated and fitted together in order to achieve the good alignement and negligible friction at low temperature. The driving mechanism at the top of the apparatus consists of a set of Belleville springs compressed with a simple screw. Springs are used in order to apply load smoothly. Furthermore they can compensate for differential thermal dilation of the set of tubes, pistons, sleeve and sample. The maximum applied load is 1500 daN.

The applied load is measured with a load cell outside of the cryostat. The actual load on the sample is determined from the elongation of the aluminium alloy sleeve as measured by strain gauge bridge. The gauges are mounted in the adjacent branches of an extensometer bridge. This arrangement ensures temperature compensation of the strain gauges and a high sensitivity of measurement. Calibration of the deformation of the sleeve is made by comparing the readings obtained from these strain gauges with those obtained from two strain gauges glued on the opposite sides of a calibration sample. The latter consists of a small parallelepiped of copper-beryllium treated at $315^{\circ} \mathrm{C}$ for $3 \mathrm{~h}$. The force which is applied to the sample is deduced from the average of the deformations measured by each strain gauge. The calibration is carried out by a series of measurements at room temperature and at liquid nitrogen temperature. 
The calibration coefficient can be extrapolated down to very low temperature leading to an accuracy of \pm 5 daN. At low temperature a temperature sensor is mounted inside the lower piston close to the sample.

Some experimental results have been already obtained by using this apparatus. We can mention neutron scattering studies of the onset of magnetic order in $\mathrm{Pr}^{3}, \mathrm{CeAl}_{2}^{4}, \mathrm{Cr}^{5}$. Ultrasonic pulse measurements and magnetic susceptibility determinations have also been performed with this versatile uniaxial stress device. Neutron data have indicated that the applied stress is uniform in the bulk sample.

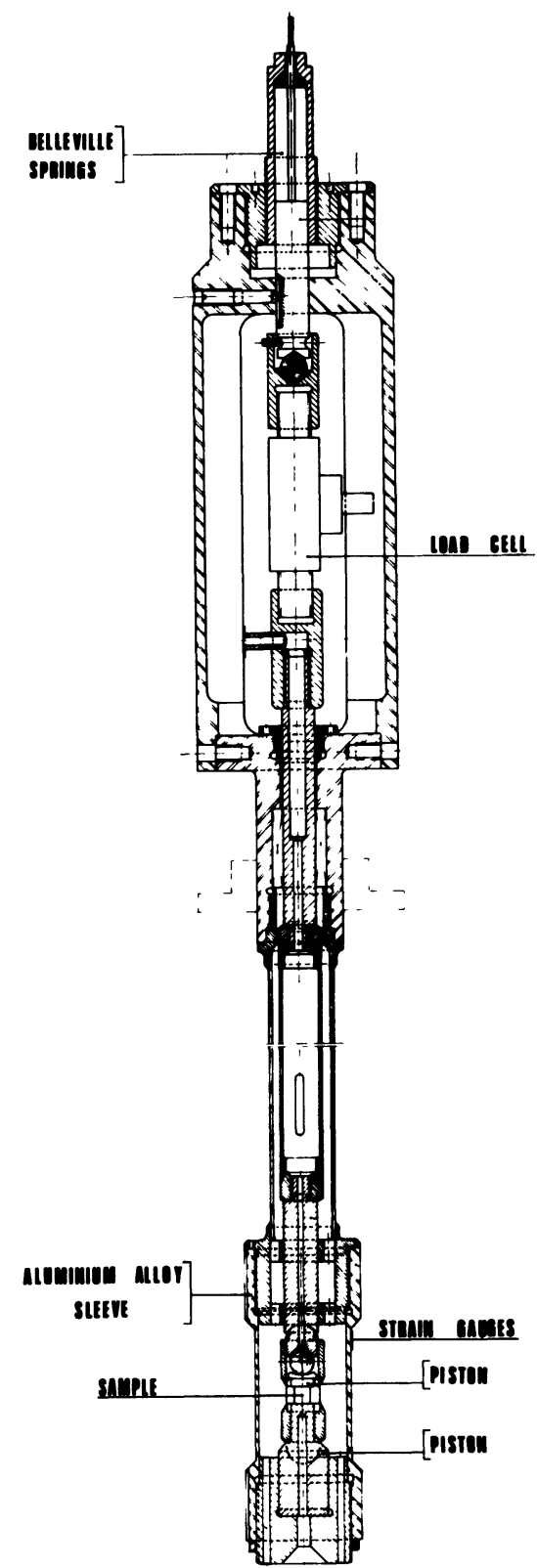

Fig. 1. - Schematic of the uniaxial stress apparatus.

\section{References}

[1] Draperi, A.. Hermann-Ronzaud. D. et Paureau. J., J. Phys. E 9 (1976) 174-175.

[2] VogelmanN, H. et Fueldly, T. A., Rev. Sci. Instrum. 45 (1974) 309-310.

[3] McEwen, K. A., Stirling, W. G. et Vettier, C., Phys. Rev. Lett. 41 (1978) 343-346.
[4] Barbara, B., Boucherle, J. X., Rossignol, M. F. et VetTier, C., Phys. Rev. Lett. 45 (1980) 938-941. [5] Fawcett. E.. Feder. D.. Muir. W. C. et Vettier. C., J. Phys. F 14 (1984) 1261-1266. 